\title{
PENGARUH PENAMBAHAN SARI BUAH NENAS PADA PERMEN KERAS
}

\author{
EFFECT OF THE ADDITION SARI PINEAPPLE HARD CANDY
}

\author{
Fetty Indriaty dan Sjamsiwarni Reny Sjarif \\ Balai Riset dan Standardisasi Industri Manado \\ Jalan Diponegoro No: 21-22 Manado \\ Pos-el: indriatyfetty@yahoo.com \\ Diterima tgl 02-08-2016, Disetujui tgl 06-09-2016
}

\begin{abstract}
ABSTRAK
Buah nanas merupakan buah yang tidak dapat disimpan dalam waktu yang lama karena kadar air yang relatif tinggi $(85,3 \%)$, menyebabkan mudah rusak, susut, dan cepat busuk. Salah satu usaha pemanfaatannya yaitu dengan mengekstrakatau mengambil sarinya dan mengolah menjadi permen.Penelitian ini bertujuan untuk mendapatkan permen nanas keras dandisukai oleh panelis dengan penambahan sari buah nanas. Metode yang digunakan adalah metode percobaan secara Rancangan Acak Lengkap, dua kali ulangan dengan dengan perlakuan penambahan sari sari buah $(0,20,25,30$ dan $35 \%)$ serta perbandingan jumlah sukrosa dan glukosa $70: 30(\% \mathrm{~b} / \mathrm{b})$. Pengamatan dilakukan terhadap mutu dari permen nanas sesuai dengan persyaratan kembang gula keras SNI 3547.1:2008 meliputi kadar air, kadar sukrosa, kadar gula reduksi, kadar abu dan vitamin C. Hasil penelitian menunjukkan penambahan sari buah nanas memberikan pengaruh nyata pada kadar sukrosa yaitu antara 63,0375,09\%, gula tereduksi 11,06-21,69\%, kadar air antara1,08-1,14\%. Kadar Vitamin C berkisar antar 1,90$2,01 \mathrm{mg} / \mathrm{g}$. Semua memenuhi syarat mutu kembang gula keras SNI3547.1:2008. Secara organoleptik rasa, bau, warna dan tekstur disukai panelis.
\end{abstract}

Kata kunci: permen keras, nanas

\begin{abstract}
Pineapple is a fruit that can not be stored for a long time because of the relatively high water content (85.3\%), causing pineapple easily damaged, shrinkage, and perishable. One of the efforts is by extracting the juice and then process it into candy. This study aimed to get pineapple hard candy and to know which one is preferred by the panelists with the addition of several concentrations of pineapple juice. The method used is the method of completely randomized design experiment, two replications by treatment with the addition of pineapple juice $(0,20,25,30$ and $35 \%)$ and the amount of sucrose and glucose ratio of $70: 30(\% \mathrm{w} / \mathrm{w})$. Observations were made on the quality of pineapple candy in accordance with the requirements of hard confectionery SNI 3547.1: 2008 covers the water content, sucrose content, reducing sugar content, ash content and vitamin $C$. The addition of pineapple juice showed significant effect on the sucrose concentration ranged from 63,03-75.09\%, reduced sugar ranged from 11.06-21.69\%, water content ranged from 1,08-1,14\%. Vitamin C content ranging between 1.90-2.01 $\mathrm{mg} / \mathrm{g}$. All candies that was produced in this research meet the quality requirements of hard confectionery SNI3547.1: 2008. Panelists also preferred its taste, odor, color and texture conducted by organoleptic test.
\end{abstract}

Keywords: hard candy, pineapple

\section{PENDAHULUAN}

Indonesia merupakan negara yang kaya akan tumbuhan hortikultura salah satu produk hortikultura yaitu buah nanas.Buah nanas mempunyai rasa yang asam sampai manis. Buah Nanas mengandung energi sebesar 52 kilokalori, protein $0,4 \mathrm{~g}$, karbohidrat $13,7 \mathrm{~g}$, lemak 0,2 g, kalsium 16 $\mathrm{mg}$, fosfor $11 \mathrm{mg}$, dan zat besi $0 \mathrm{mg}$. Selain itu di dalam Buah Nanas juga terkandung vitamin A sebanyak $130 \mathrm{IU}$, vitamin B1 0,08 miligram dan vitamin C 24 miligram danjumlah bagian yang dapat dimakan sebanyak 53\%.Nanas termasuk buah tidak dapat disimpan dalam waktu yang agak lama karena kadar air yang relatif tinggi $(85,3 \%)$ menyebabkan nanas 
mudah rusak, susut, dan cepat busuk(1). Salah satu usaha pemanfaatannya yaitu dengan mengekstrak atau mengambil sarinya dan mengolah menjadi permen.

Permenmerupakan salah satu bentuk makanan olahan dari pendidihan campuran gula dan sari buah atau bahan tambahan pangan pemberi flavor. Permen adalah suatu produk yang diharapkan dapat mempertahankan bentuknya dalam waktu yang cukup lama, dan tidak rusak baik karena pengaruh kimiawi ataupun mikrobiologi sebelum permen tersebut dikonsumsi.Hal yang perlu diperhatikan dalam pembuatan permen adalah kelarutan sukrosa. Permen yang menggunakan sukrosa murni mudah mengalami Kristalisasi. Oleh karena itu perlu digunakan bahan lain untuk meningkatkan kelarutan dan menghambat kristalisasi, misalnya sirup glukosa(2).

Permen berdasarkan jenisnya dikelompokkan menjadi dua macam yaitu permen kristalin (krim) dan permen non kristalin (amorphous). Permen kristalin biasanya mempunyai rasa yang khas dan apabila dimakan terdapat rasa krim yang mencolok. Sedangkan permen non kristalin (amorphous) terkenal dengan sebutan without form, berdasarkan teksturnya dibedakan menjadi permen keras/hard candy(hard boiled sweet), permen kunyah (chewy candy) atau permen lunak (soft candy), gum dan jelly(3).Permen yang jernih dapat dihasilkan dengan kandungan air yang rendah dan penambahan sirup glukosa yang akan mempertahankan viskositas tinggi(4). Formulasi dalam pembuatan permen sangat penting dan sangat menentukan karakteristik produk.
Penambahan sari buah nanas diharapkan dapat menggantikan bahan tambahan pangan untuk Flavor pada permen keras dengan memberikan nilai tambah terhadap buah nanas. Parameter yang berperan terhadap mutu permen yaitu kadar air, kadar sukrosa, kadar gula reduksi, kadar vitamin C, kadar abu dan penilaian organoleptik. Menurut SNI 3547.1:2008 persyaratan produk kembang gula keras adalah kadar air maksimal 3,5\%,sukrosa minimal $35 \%$,gula reduksi maksimal 24\%dan abu maksimal 2,0\%(5). Penelitian ini bertujuan untuk mendapatkan permen keras dari buah nanas dan disukai panelis.

\section{BAHAN DAN METODE}

\section{Bahan dan Alat}

Bahan- bahan yang digunakan dalam penelitian ini terdiri dari buah nanas(ananas comosus) diperoleh dari pasar lokal, gula pasir(sukrosa), glukosa diperoleh dari tokobahan kimia di Bandung, kemasan plastic PP dan kemasan Aluminium foil yang dilapisi plastic laminasi PE dan bahan-bahan kimia untuk uji laboratorium.

Alat-alat yang digunakan dalam penelitian ini adalah Juice ekstraktor,merek madato, Loyang plastic, pisau, hot plate, kain saring, timbangan, thermometer, cetakan permen, panci, gelas ukur dan hand sealer.

\section{Metode Penelitian}

Penelitian ini menggunakan metode percobaan yang disusun dalam Rancangan Acak Lengkap. Perlakuan yang digunakan yaitu konsentrasi penambahan sari buah nanas yaitu $0,20,25,30$ dan $35 \%$. 
Komposisi perbandingan sukrosa dan glukosa 70:30 (b/b).

Penelitian ini dilaksanakan dalam beberapa tahap yaitu: Pembuatan ekstrak sari buahnanas dan pembuatan permen. Pembuatan permen akan dilakukan menggunakan metode percobaan yang disusun dalam Rancangan Acak Lengkap dengan 2 kali ulangan sesuai dengan perlakuan dan pengujian mutu permensesuai SNI. 3547.1:2008.

\section{Prosedur Kerja}

Buah nanas yang sudah matang, dikupas, dikeluarkan mata/biji buah, dicuci dan diambil dagingnya. Setelah itu daging buah dipotong-potong dalam ukuran lebih kecil, kemudian dihancurkan menggunakan juice ekstraktor. Setelah itu sari buah nanasdipekatkan sampai kadar padatan terlarut $8{ }^{\circ}$ Brix. Selanjutnya ditimbang sesuai perlakuan $0,20,25,30$ dan $35 \%$.

Tahap kedua menyiapkan komposisi sukrosa dan glukosa 70:30 g. sukrosa kemudian dilarutkan dalam air, dimasak sampai kental mencapai suhu $110^{\circ} \mathrm{C}$. Ditambahkan glukosa dan diaduk sampai merata atau homogen.

Tahap ketiga penambahan sari buah nanas, diaduk sampai mencapai suhu $140^{\circ} \mathrm{C}$. Angkat, dinginkan sampai suhu sekitar $60^{\circ} \mathrm{C}$, tuangkan dalam cetakan. Permen nanas dikemas dengan plastik PP. Permen nanas siap untuk dianalisis.Diagram alir proses pengolahan permen keras dapat dilihat pada gambar 1 dan 2.

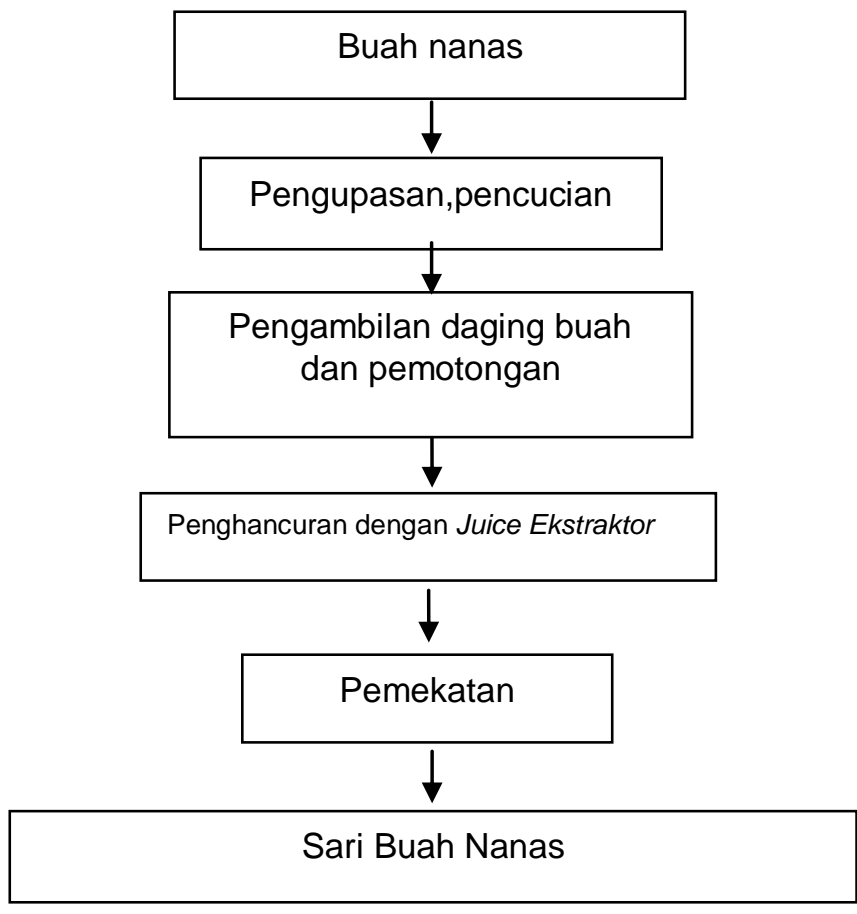

Gambar 1. Proses ekstraksi sari buah nanas. 


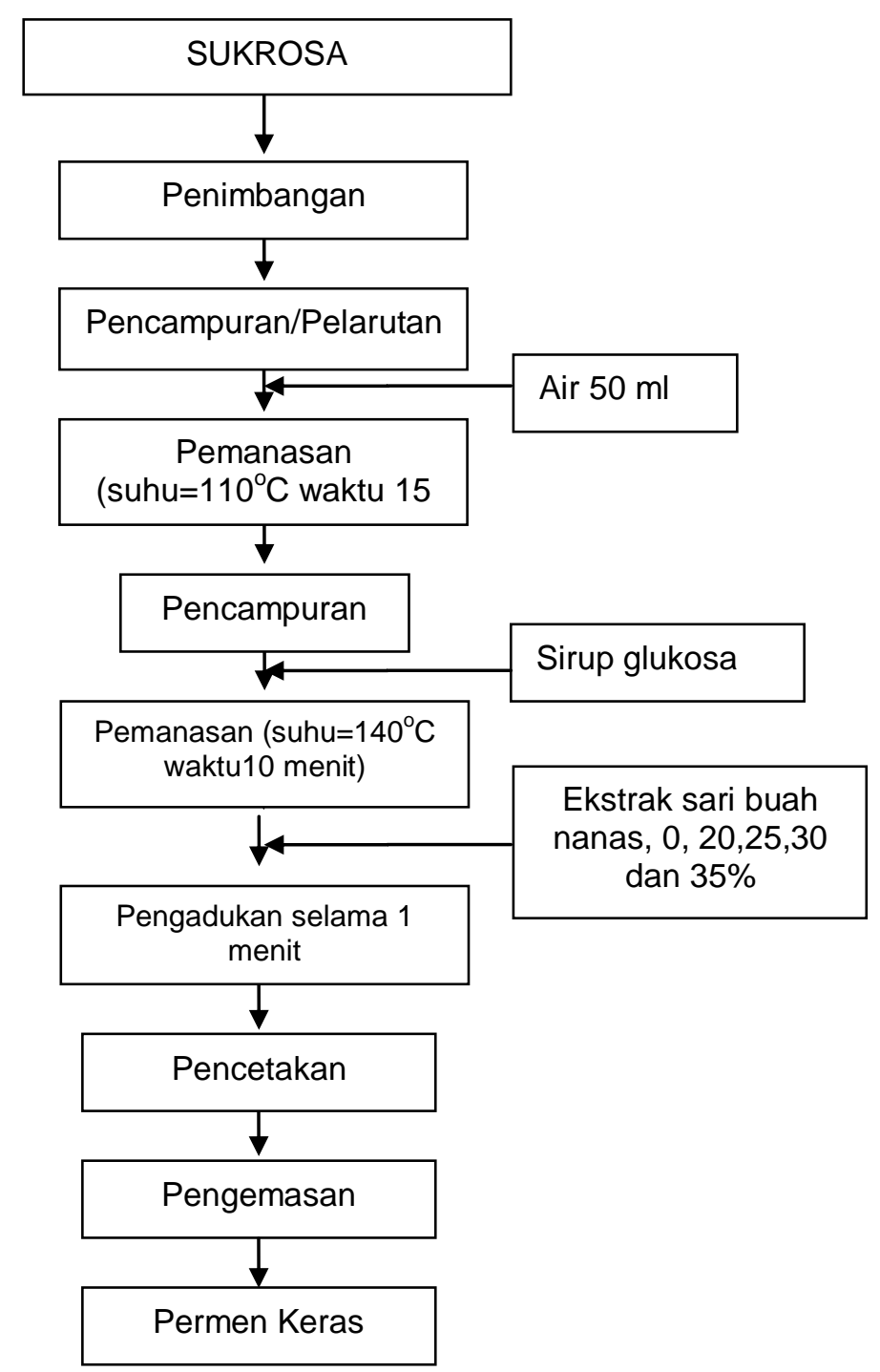

Gambar 2. Diagram alir proses pengolahan permen keras

\section{Variabel yang diamati}

Pengamatan dilakukan terhadap mutu permen nanas sesuai persyaratan kembang gula keras SNI 3547.1:208.meliputi kadar air (oven), sukrosa(luff schorll), gula reduksi (luff schorll), kadar abu (gravimetri), kadar Vitamin C (Titrimetri). Uji organoleptik (skala hedonik) yaitu skala 1-5 dimana 5 (sangat suka), 4 (suka), 3 (agak suka), 2 (tidak suka), 1 (sangat tidak suka).Data yang diperoleh dianalisis menggunakan Analisis Varians dan dilanjutkan dengan uji beda nyata terkecil apabila ada pengaruh perlakuan terhadap parameter yang diukur.

\section{HASIL DAN PEMBAHASAN}

\section{Kadar Air}

Kadar air sangat berpengaruh terhadap mutu dari permen, karena tingkat keawetan permen mempunyai hubungan yang erat dengan kadar air yang dikandungnya. Semakin tinggi penambahan sari buah nanas, kadar airnya permen keras semakin tinggi (6). 


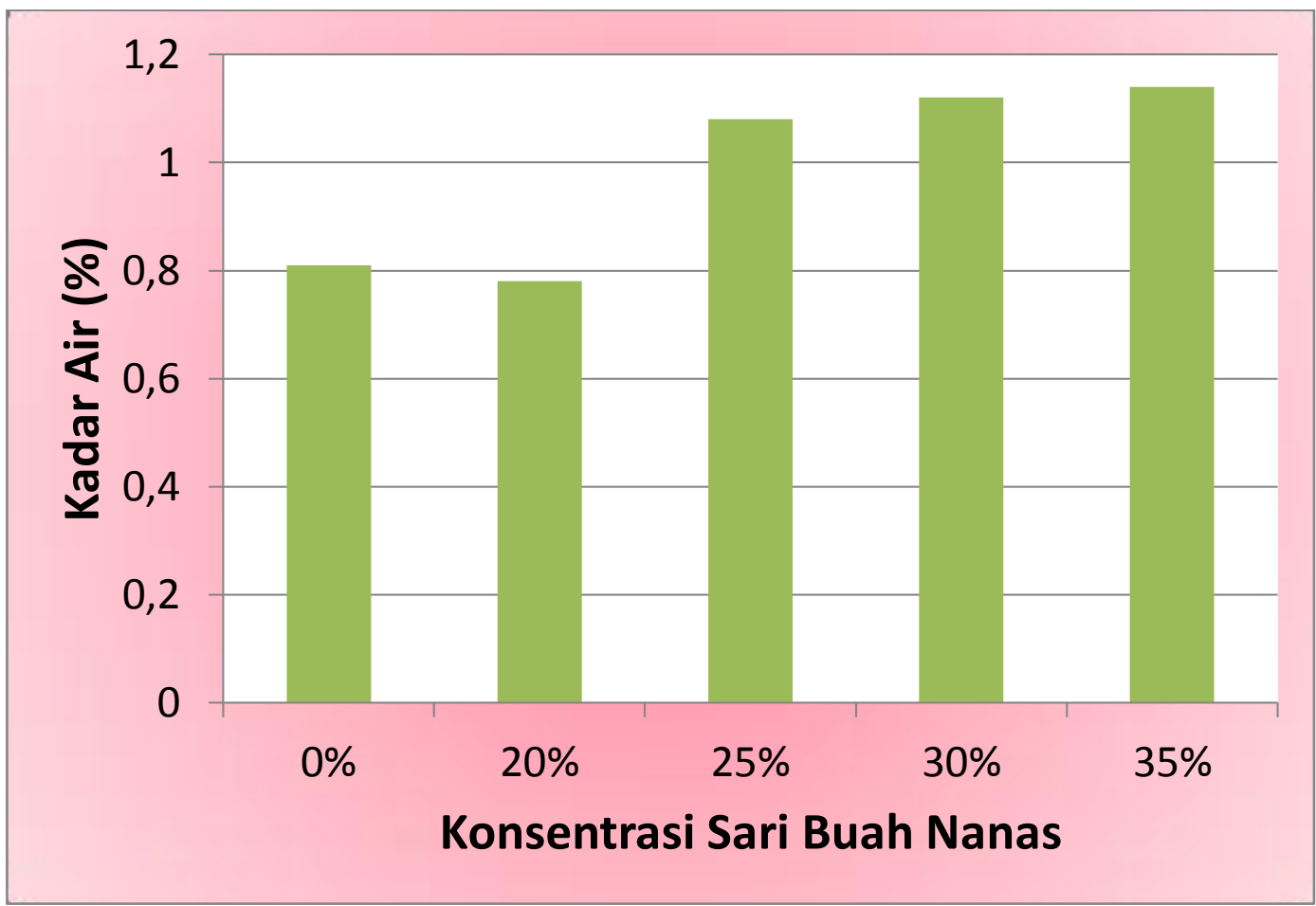

Keterangan: $\mathrm{N}=$ Konsentrasi sari buah nanas

$\mathrm{N} 0=0 \%, \mathrm{~N} 20=20 \%, \mathrm{~N} 25=25 \%, \mathrm{~N} 35=35 \%$

\section{Gambar 3.Pengaruh Penambahan Sari Buah Nanas terhadap Kadar Air Permen}

Hasil analisis laboratorium menunjukkan bahwa kadar air rata-rata permen nanas berkisar antara 1,08-1,14\% . Hasil analisis varians penambahan sari buahnanas pada permen memberikan pengaruh nyata terhadap kadar air dari permendengan syarat mutu kembang gula keras SNI 3547.1:2008yaitu maksimal $3,5 \%(5)$. Dengan persentase penambahan sari buah yang digunakan dapat mengakibatkan kenaikan kadar air pada produk akhirnya(7). Hal ini dikarenakan jumlah sari buah nanas yang ditambahkan banyak mengandung air sehingga berpengaruh meningkatkan kadar air terhadap produk akhir.Kadar air sari buah nanas yaitu $85,3 \%$.Pada proses pembuatan permen mengunakan sukrosa dan glukosa 70:30 diduga sukrosa yang ditambahkan dapat mengikat air karena sifatnya yang menyebabkan gula dapat mengurangi kadar air pada bahan pangan yangditambahkan(8).

\section{Kadar Sukrosa}

Kadar sukrosa merupakan salah satu parameter yang mempengaruhi mutu dari permen. Dalam pembuatan permen perbandingan antara sukrosa dan glukosa harus diperhatikan karena kesalahan rasio akan dapat menyebabkan graining/kristalisasi dan juga sticking/lengket(9). 


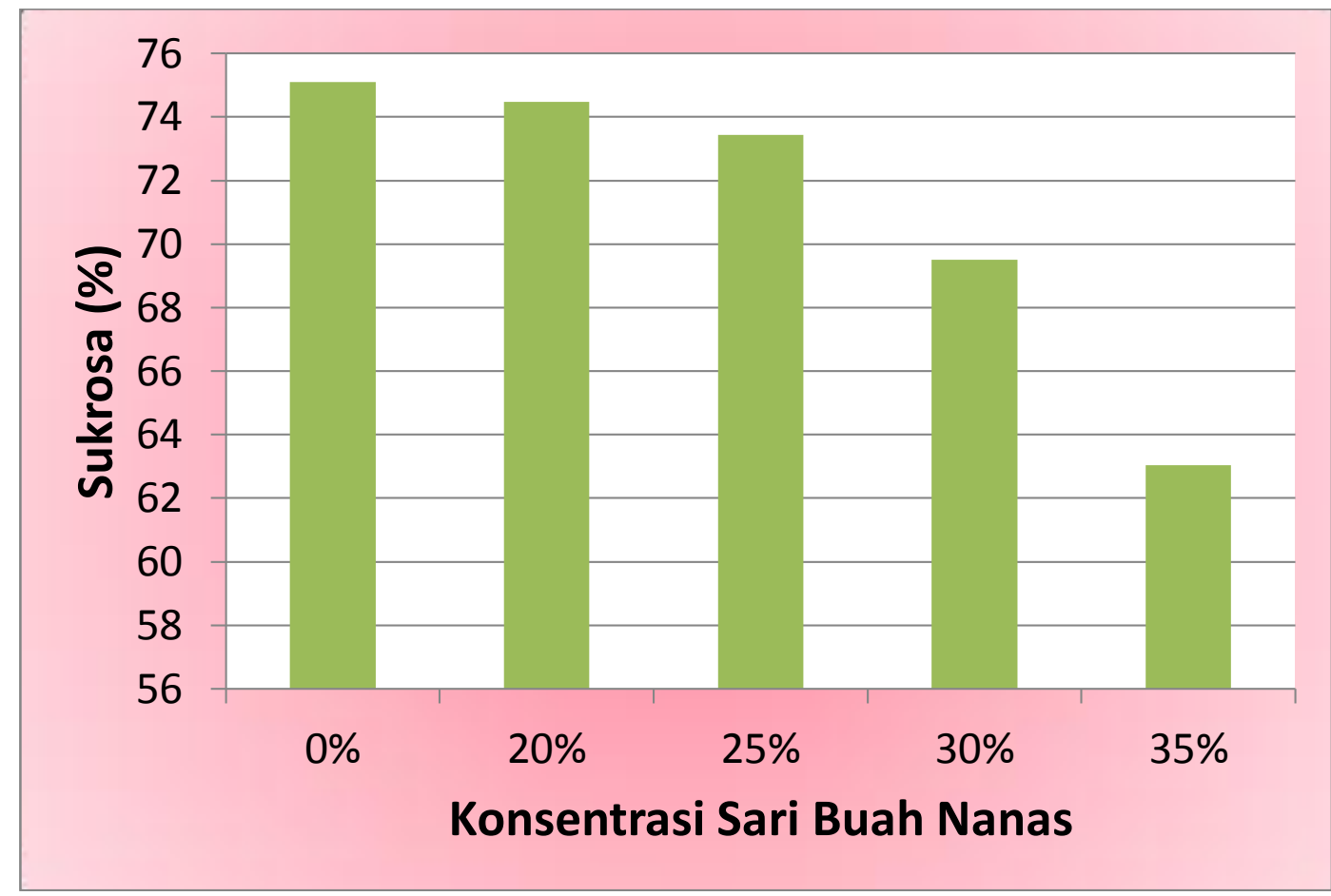

Keterangan: $\mathrm{N}=$ Konsentrasi sari buah nanas $\mathrm{N} 0=0 \%, \mathrm{~N} 20=20 \%, \mathrm{~N} 25=25 \%, \mathrm{~N} 35=35 \%$

Gambar 4. Pengaruh Penambahan Sari Buah Nanas Terhadap Kadar Sukrosa Permen

Hasil pengujian laboratorium memperoleh hasil rata-rata kadar sukrosapermen dengan perlakuan penambahan sari buah nanas berkisar 63,03-75,09\%. Kadar sukrosa tertinggi terdapat pada perlakuan tanpa penambahan sari buah nanas yaitu $0 \%$ (N0) dan kadarsukrosa permen terendah pada perlakuan penambahan sari buah nanas 35\% (N35). Setelah dilakukan analisis varians perlakuan penambahan sari buah nanas, memberikan pengaruh yang berbeda. Sukrosa digunakan dalam pembuatan permen keras umumnya sebanyak $50-70 \%$ dari berat total. Hasil penelitian Wahyuni, menunjukkan bahwa peningkatan kadar sukrosa akan meningkatkan kekentalannya agar dihasilkan permen dengan kejernihan yang baik atau penampakan mirip air dibutuhkan gula dengan tingkat kemurnian yang tinggi(6). Permen yang menggunakan sukrosa murni mudah mengalami kristalisasi oleh karena itu, perlu digunakan bahan lain untuk menghambat kristalisasi misalnya sirup glukosa sirup maltosa, dextrosa, gula invert atau high fructose syrup. Semua perlakuan penambahan sari buah nanas yang digunakan menghasilkan permen dengan kadar sukrosa memenuhi syarat mutu kembang gula keras SNI $3547.1: 2008$ yaitu minimal 38\%(5).

\section{Kadar Gula Reduksi}

Salah satu parameter penting dalam penentuan mutu permen adalah gula reduksi. Gula reduksi yaitu gula yang mempunyai kemampuan untuk mereduksi, karena adanya gugus aldehid atau keton. Gula yang termasuk gula reduksi yaitu 
glukosa, fruktosa, manosa, laktosa, maltose

reduksi adalah sukrosa(10).

dan lain-lain. Gula yang termasuk non

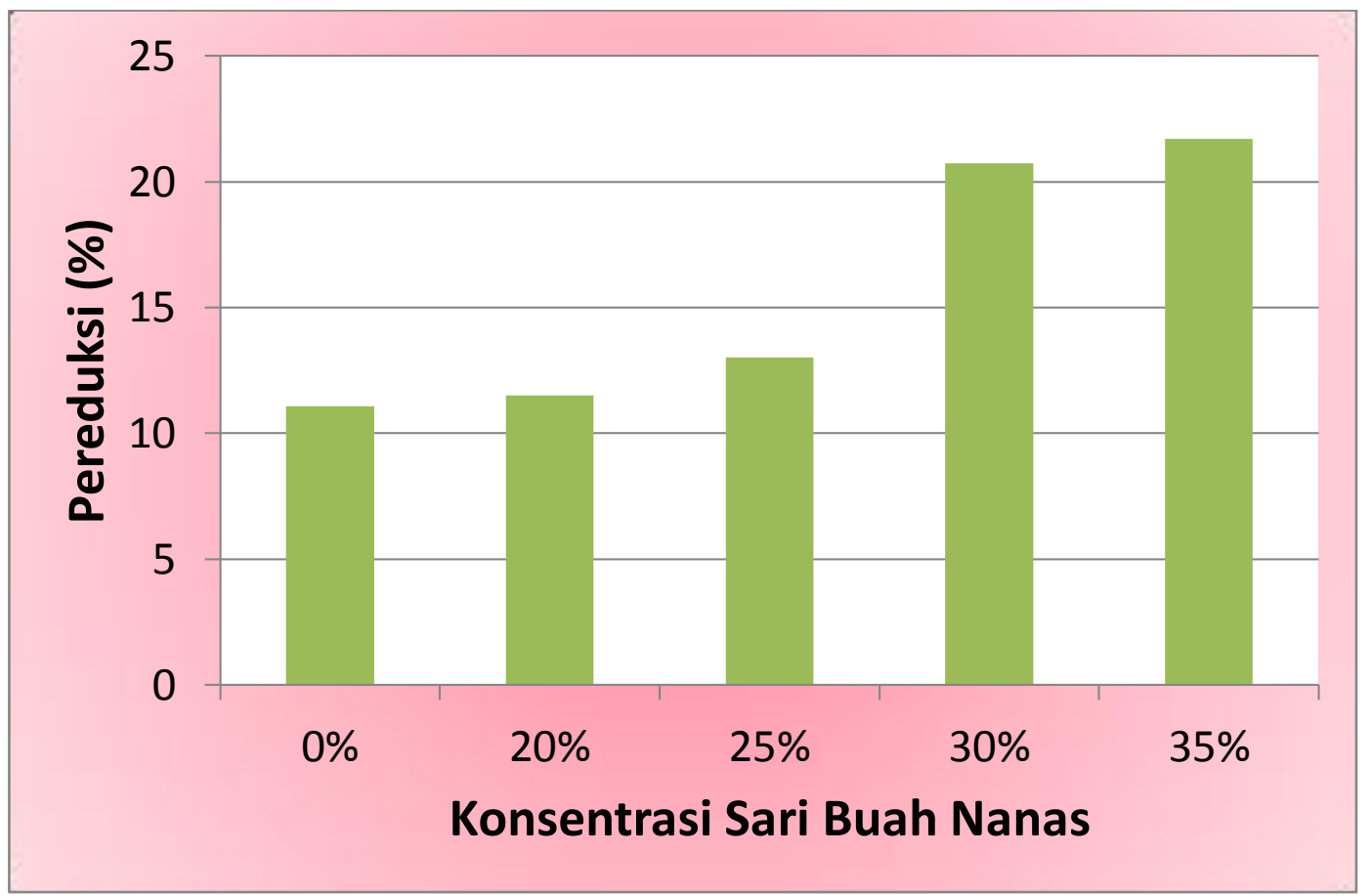

Keterangan: $\mathrm{N}=$ Konsentrasi sari buah nanas

$\mathrm{N} 0=0 \%, \mathrm{~N} 20=20 \%, \mathrm{~N} 25=25 \%, \mathrm{~N} 35=35 \%$

Gambar 5. Pengaruh Penambahan Sari Buah Nanas Terhadap Gula Pereduksi Permen

Hasil analisis rata-rata nilai gula reduksi dari permen dengan perlakuan sari buah nanas yaitu, berkisar 11,06-21,69\% pada Gambar.5 hasil perlakuan penambahan sari buah pada permen memberikan pengaruh yang berbeda pada kadar gula reduksi. Perlakuan penambahan sari buah nanas $35 \%$ diperoleh kadar gula reduksi tertinggi yaitu, sebesar 21,69\%. Hal ini diduga padakadar gula pereduksi dari permen keras dengan penambahan sari buah nanas cenderung meningkat dengan makin tingginya persentase penambahan sari buah. Hal ini diduga karena sifat asam dari buah nanas yang ditambahkan. Permen yang diproses menggunakan bahanbaku sari buah yang bersifat asam akan memiliki gula reduksi yang tinggi karena sebagian sukrosa akan terinversi menjadi gula reduksi yaitu glukosa, fruktosa atau campuran keduanya (gula invert). Gula pereduksi terbentuk karena terjadinya proses inverse ataupun hidrolisis asam dari sukrosa menjadi glukosa dan fruktosa(11). $\mathrm{Hal}$ ini sesuai dengan pendapat Winarnobahwa peningkatan gula pereduksi disebabkan selama proses pendidihan larutan sukrosa mengalami inverse atau pemecahan sukrosamenjadi glukosa dan fruktosa akibat pengaruh asam dan panas yang akan meningkatkan kelarutan gula(17). Hal ini juga didukung Ashurts bahwa proses invesi meningkat dengan adannya reaksi dari asam, panas dan kandungan mineral, secara terpisah maupun dikombinasikan(13). Perlakuan 
penambahan sari buah nanas terhadap gula reduksi memenuhi syarat mutu kembang gula keras SNI 3547.1:2008 yaitu maksimal 24\%(5).

\section{Kadar Vitamin C}

Vitamin $\mathrm{C}$ adalah asam organik yang terasa asam, berbentuk kristal putih, akan lebih tahan terhadap panas lama, stabil dalam bentuk kering tetapi mudah teroksidasi dalam keadaan larutan dan basa(14).

Semakin banyak penambahan sari buah yang ditambahkan maka kandungan vitamin C-nya semakin tinggi. Gula akan mengikat vitamin $\mathrm{C}$ pada saat dilakukan pemanasan sehingga kerusakan vitamin C akibat pemanasan dapat diperkecil. Pemanis atau gula juga bertindak sebagai pengikat komponen(15).

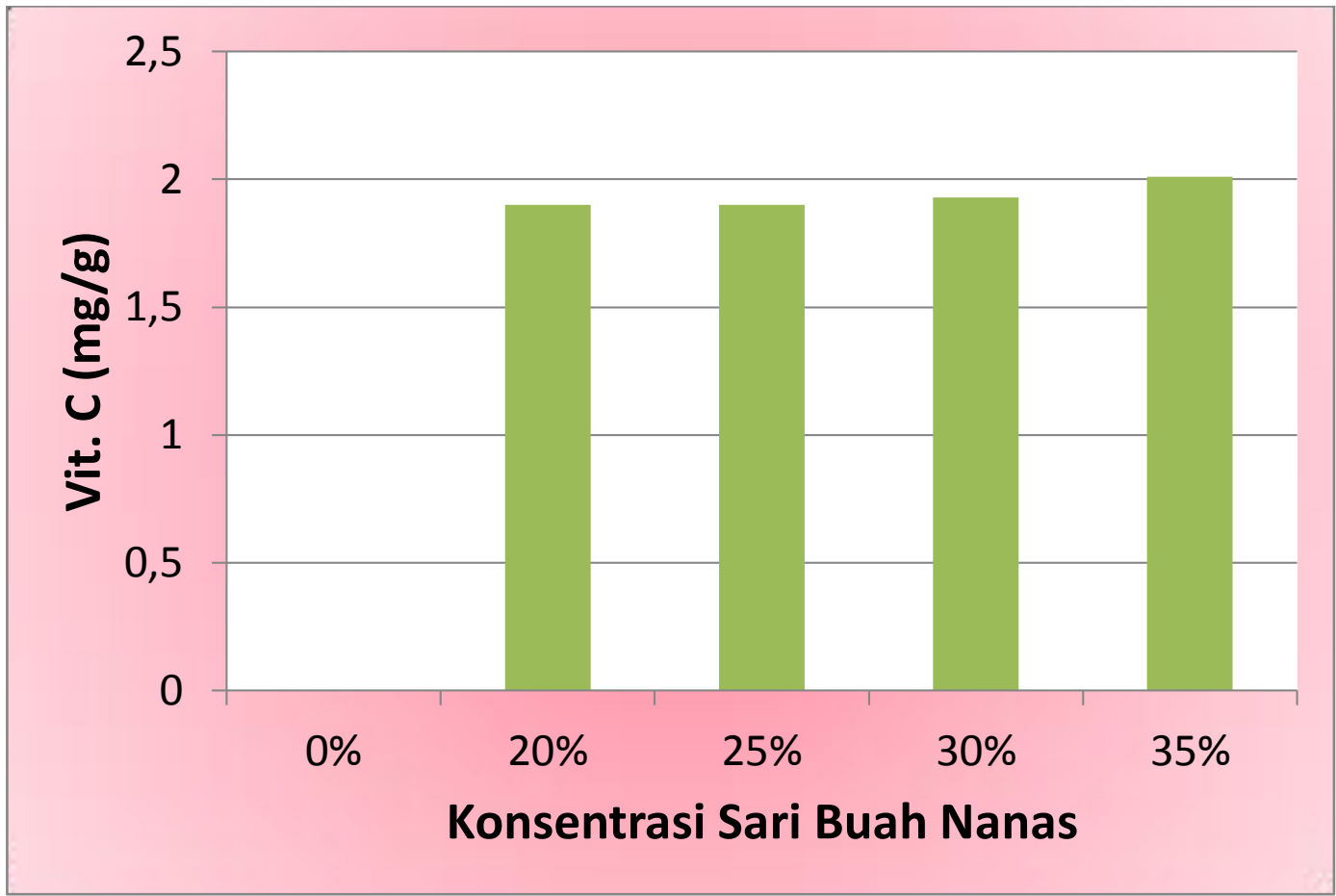

Keterangan: $\mathrm{N}=$ Konsentrasi sari buah nanas $\mathrm{N} 0=0 \%, \mathrm{~N} 20=20 \%, \mathrm{~N} 25=25 \%, \mathrm{~N} 35=35 \%$

Gambar 6. Pengaruh Penambahan Sari Buah NanasTerhadap Vitamin C Pada Permen

Hasil analisis laboratorium menunjukkan bahwa kadar vitamin $\mathrm{C}$ pada permen nanas berkisar antara 1,90-2,01 mg/g. Sedangkan kandungan vitamin $\mathrm{C}$ pada buah nanas 24 mg(16).Vitamin C mempunyai sifat asam dan sifat pereduksi yang kuat(3).Vitamin C dapat berbentuk sebagai asam askorbat.Asam dalam permen keras selain sebagai gizi juga dibutuhkan untuk membantu pembentukan gula pereduksi.

Rendahnya vitamin C hasil penelitian diduga pada proses penyiapan sari buah yang digunakan sebagai bahan tambahan pada permen yaitu melalui tahap-tahap pengirisan, penghancuran, pemanasan sehingga vitamin $\mathrm{C}$ banyak yang hilang. 
Karena vitamin C mudah larut dalam air dan mudah rusak oleh proses oksidasi, panas, dan alkali. Oleh karena itu hindari proses pencucian, pengirisan buah nanas yang berlebihan.

\section{Kadar Abu}

Kadar abu adalah salah satu syarat mutu permen keras karena dengan semakin rendah kandungan abu dalam permen, maka penampakan dari permen akan semakin baik.

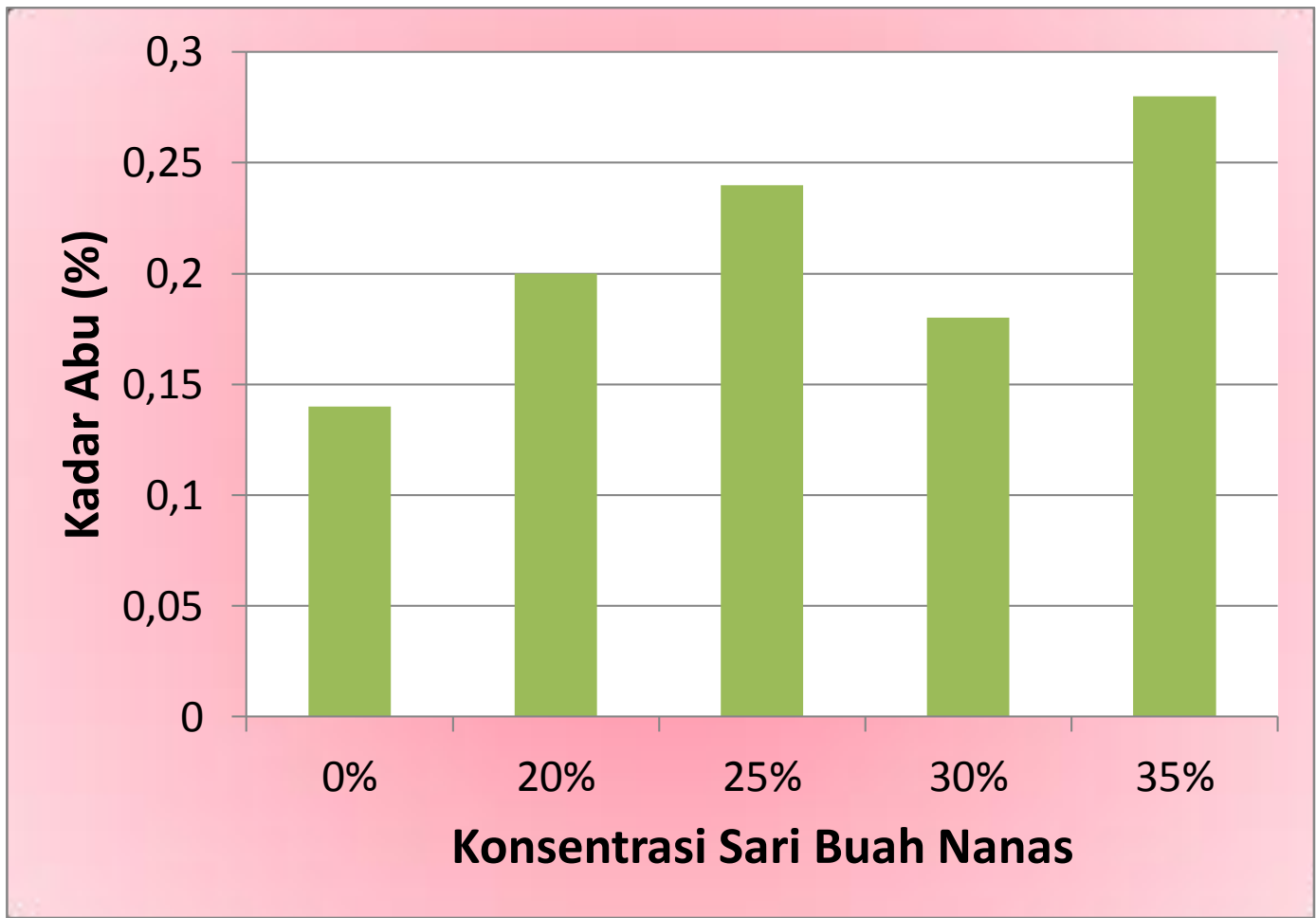

Keterangan: $\mathrm{N}=$ Konsentrasi sari buah nanas

$\mathrm{NO}=0 \%$, N20 = 20\%, N25 = 25\%, N35=35\%

\section{Gambar 7. Pengaruh Penambahan Sari Buah Nanas Terhadap Kadar Abu Pada Permen}

Hasil analisis kadar abu produk permen nanas berkisar antara 0,14-0,28\%. Dari hasil tersebut dapat dilihat bahwa dengan semakin banyak penambahan sari buah nanas kadar abu permen semakin tinggi dan juga bahan baku permen seperti gula pasir (sukrosa) berpengaruh terhadap kadar abu dari permen yang dihasilkan(3). Dibandingkan dengan syarat mutu kadar abu dari kembang gula keras(SNI.3547.1:2008) yaitu maksimal 2,0\%(5). Maka kadar abu dari permen nanas memenuhi syarat mutu. Ini menunjukkan bahwa bahan baku permen yang digunakan yaitu gula (glukosa, gula invert dan sukrosa), dan sari buah nanas memiliki kandungan abu yang cukup untuk pembuatan permen sehingga kadar abu yang dihasilkan memenuhi syarat mutu.

Gula dengan tingkat kemurnian tinggi dan kandungan abunya rendahakan menghasilkan permen dengan kejernihan yang baik atau penampakan mirip air(3)(6). Kandungan abu yang tinggi menyebabkan peningkatan inversi, pewarnaan dan pembusaan selama pemasakan sehingga memperbanyak gelembung udara yang terperangkap dalam masa gula. 
Pengujian Organoleptik

Hasil pengujian organoleptik pengaruh penambahan sari buah nanas

Tabel 1. Pengaruh Penambahan Sari buah Nanas Terhadap Hasil Pengujian Organoleptik Terhadap Tingkat Kesukaan Rasa, Bau, Warna, Tekstur dari PermenNanas.

\begin{tabular}{ccccc}
\hline Perlakuan & Rasa & Bau & Warna & Tekstur \\
\hline N0 & 4.14 & 3.62 & $4.37 \mathrm{~b}$ & $4.54 \mathrm{~b}$ \\
N20 & 4.16 & 4.21 & $4.24 \mathrm{~b}$ & $4.5 \mathrm{~b}$ \\
N25 & 4.29 & 4.25 & $4.38 \mathrm{~b}$ & $4.28 \mathrm{ab}$ \\
N30 & 4.38 & 4.37 & $4.04 \mathrm{~b}$ & $3.78 \mathrm{~b}$ \\
N35 & 4.5 & 4.58 & $3.58 \mathrm{a}$ & $3.79 \mathrm{~b}$ \\
\hline
\end{tabular}

Hasil penelitian

Keterangan:

$\mathrm{N}=$ Konsentrasi sari buah nanas

$\mathrm{N} 0=$ nanas $0 \%, \mathrm{~N} 20=$ nanas $20 \%, \mathrm{~N} 25=$ nanas $25 \%$, N35= nanas $35 \%$

Nilai kesukaan: $1=$ sangat tidak suka, $2=$ tidak suka, $3=$ cukup suka, $4=$ suka

Hasil Pengujian organoleptik menunjukkan bahwa nilai rata-rata tingkat kesukaan panelis terhadap rasa, bau, warna dan tekstur berkisar antara 3,62-4,58 (suka-sangat suka). Untuk rasatingkat kesukaan panelis terhadap permen pada penambahan sari buahnanas berkisar 4.144,50 (suka-sangat suka). Hasil analisis varians penambahan sari buahnanas tidak memberikan perbedaan tingkat kesukaan terhadap rasa. Rasa permen pada perlakuan penambahan sari buahnanas kemungkinan disebabkan berkurangnya rasa khas buah tersebut, diduga akibat proses pemanasan.Namun pada tabel1 rata-rata nilai tingkat kesukaan pada permen berbanding lurus hal ini dapat dilihat semakin banyak sari buahnanas yang ditambahkan pada permen, semakin disukai panelis.

Bau merupakan parameter penting dalam industri makanan karena dengan cepat dapat memberikan hasil penilaian diterima atau tidaknya suatu produk(6). Bau suatu produk sangat berpengaruh terhadap selera konsumen yang berkaitan dengan indera penciuman sehingga menimbulkan keinginan untuk mengkonsumsi. Bau yang enak akan menggugah selera, sedangkan bau yang tidak enak akan menurunkan selera konsumen untuk mengkonsumsi produk tersebut(3).Bau dapat diartikan harum, busuk dan sebagainya. Bau sukar diukur karena biasanya menimbulkan pendapat yang berbeda. Rata-rata panelis menyukai bau dari permen nanas. Tingkat kesukaan bau dari permen yang ditambahkan sari buah nanas, rata-rata berkisar 3,62-4,58 (suka-sangat suka).Berdasarkan data tersebut, perlakuan penambahan sari buah nanasjuga tidak memberikan pengaruh yang nyata pada tingkat kesukaan bau permen yang ditambahkan sari buah nanas.Nilai tingkat kesukaan terhadap bau dari permen pada tabel 1, dapat dilihat bahwa cendenrug meningkat denganmakin bertambahnya konsentrasi penambahan sari buah nanas. Hasil pengujian organoleptik menunjukkan bahwa nilai rata-rata tingkat kesukaan panelis terhadap warna berkisar antar 3,584,38 (suka - sangat suka). Hasil analisis varians perlakuan penambahan sari buah nanas memberikan perbedaan pada 
tingkatkesukaan warna permen.Semakin tinggi penambahan sari buahnanas pada permen, semakin menurun tingkat kesukaan panelis.

Semakin banyak penambahan sari buah pada permen, warna permen yang dihasilkan yaitu menjadi coklat tua. Menurut Winarno jika sukrosa dipanaskan terus sampai titik leburnya yaitu $160^{\circ} \mathrm{C}$ maka akan terjadi proses karamelisasi(18). Reaksi yang terjadi merupakan reaksi pencoklatan non-enzimatis yaitu reaksi karamelisasi yang menyebabkan permen menjadi gelap. Proses tersebut adalah setiap molekul sukrosa dipecah menjadi glukosa dan fruktosa, dimana suhu tinggi mampu mengeluarkan molekul air darimolekul gula, sehingga terbentuk glukosan danfruktosan (dehidrasi). Setelah proses pemecahan dan dehidrasi adalah reaksi polimerisasi yaitu terbentuknya komponen polimer yang berwarna, menyebabkan larutan berwarna gelap.

Nilai rata-rata tingkat kesukaan tekstur permen pada penambahan sari buahnanas, tidak memberikan pengaruh nyata pada tingkat kesukaan tekstur.Nilai tingkat kesukaan tekstur terendah pada perlakuan penambahan sari buahnanas 35\%(N35) yaitu sebesar3,79 (suka). Makin banyak persentasi penambahan sari buah, nilai tingkat kesukaan terhadap tekstur menurun.

Pembentukan tekstur produk selain dipengaruhi oleh komposisi sirup glukosa dan sukrosa juga dipengaruhi oleh penambahan sari buah pada produk permen tersebut. Sirup glukosa berpengaruh untuk memperbaiki tekstur dan memiliki sifat higroskopis yang rendah sehingga dapat digunakan sebagai pelindung pada permen.

Menurut Ward dan Court campuran glukosa dalam permen dapat membuat tekstur yang dihasilkan lebih liat dan kekerasannya cenderung menurun(19). Hal inilah yang menyebabkan permen akan lebih sulit saat dicetak sesuai bentuk yang diinginkan, sehingga konsumen tidak menyukainya.

\section{KESIMPULAN}

Perlakuan penambahan sari buahnanas memberikan pengaruh pada kadarsukrosa, gula tereduksi, kadar air, tingkat kesukaan terhadap warna dan tekstur dan tidak memberikan pengaruh berbeda pada tingkat kesukaan terhadap rasa, bau dari permen.

Hasil penelitian menunjukkan penambahan sari buahnanas memberikan pengaruh pada kadar sukrosa yaitu antara $63,03-75,09 \%$, gula tereduksi 11,06$21,69 \%$, kadar air antara 0,78-1,14\%. Kadar vitamin C berkisar antara 1,90-2,01 $\mathrm{mg} / \mathrm{g}$. Semua memenuhi syarat mutu kembang gula keras SNI3547.1:2008. Secara organoleptik rasa, bau, warna dan tekstur disukai penelis.

\section{DAFTAR PUSTAKA}

1. Santoso HB. Nanas kering.Jakarta: Kanisius;1998.

2. Herschdoerfer. quality control in food industry Vol. 3. London and New York:Academic Press; 1972. 
3. Nurwati. Formulasi hard candy dengan penambahan ekstrak sari buah pidada (sonneratia ca sclolaris) sebagai flavour.Bogor: Departemen Teknologi Hasil Perairan Fakultas Perikanan dan IImu Kelautan,IPB;2011.

4. Faridah A. Patiseri jilid 3. Jakarta:Jendral Manajemen Pendidikan Dasar dan Menengah Departemen Pendidikan Nasional;2008.

5. Badan Standardisasi Nasional. SNI3541.12008. Kembang gula keras; 2008

6. Wahyuni HD. Mempelajari pembuatan hard candy dari gul invert sebagai alternatif pegganti sirup glukosa (skripsi).Bogor: Fateta, IPB; 1998.

7. Wati AS. Formulasi serbuk minuman markisa ungu ( passiflora edulis $f$ edulis. sims ) dengan metode pencampuran kering. Bogor:Skripsi, Institut Pertanian Bogor;2003.

8. Buckle KA, Edwards RA, FleetGH and Wooton M.llmu Pangan Penejemah(Hari Purnomo dan Adiono), Jakarta:W Press;1987.

9. Jackson EB. Sugar confectionery manufacture. London: Blackie Academic and Profesional;1995.

10. Sularjo. Pengaruh perbandingan gula pasir dan daging buah terhadap kualitas permen pepaya. Magistra; 2010. 74:39-48.

11. Yazaka,I.M dan Susanto WH. Karakterisasi hard candy jahe berbasis nira kelapa. Pangan dan Agroindustri. Malang: Jur Teknologi Hasil Pertanian Universitas Brawijaya Malang; 2015: Vol 3.

12. Ashurts PR. Food Flavoring (Ed.). New York: The AVI Publ; 1991.

13. Makalah-vitamin-c. https://lailasafitri.wordpress.com/2013/01/0 9/-igd/. 2013. Diakses tanggal 20 Maret 2016.

14. Fachruddin L. Membuat aneka sari buah. Yogyakarta: Kanisius; 2003.

15. Kandungan gizi buah nanas. http://www.organisasi.org/1970/01/isikandungan-gizi-buah-nanas-komposisinutrisi-bahan-makanan.html. Akses tanggal Agustus 2016.

16. Heni DW. Mempelajari pembuatan hard candy dari gula invert sebagai alternatif penganti sirup glukosa.Jurusan Teknologi Pangan dan Gizi, Fakultas Teknologi Pertanian, Institut Pertanian Bogor: Bogor; 1998.

17. Winarno FG.Kimia pangan dan gizi. Jakarta: PT. Gramedia;2008.
18. Ward and Courts. The science of technology of gelatin.London: Academic Press;1977. 